\title{
Culturally Immersed Legal Terminology on the Example of Forest Regulations in Poland, The United Kingdom, The United States of America and Germany
}

\author{
Paula Trzaskawka ${ }^{1}$ [D Joanna Kic-Drgas ${ }^{1}$
}

Accepted: 31 December 2020 / Published online: 10 February 2021

(C) The Author(s) 2021

\begin{abstract}
The importance of forests is reflected in the national forest legislation which has been developed and implemented in European countries over recent years. Due to regional and national specificities, forest regulations include culturally immersed terms specific to the described area. The aim of this paper is to analyses the culturally driven legal terms existing in specific legal regulations concerning forestry in Germany, the United Kingdom, the United States of America and Poland, and identify possible ways of translating them. In order to take the interdisciplinary nature of the issue into account, the degree of hybridity of the selected texts will be examined by means of corpus analysis. The methodology applied in the paper uses a comparative approach. Additionally, the authors also resort to the aforementioned corpus analysis, as well as the analysis of comparable texts and the analysis of terminology according to the three categories of equivalence as determined by Šarčević (New Approach to Legal translation, Kluwer Law International, Hague, 1997), and the techniques of providing equivalents for non-equivalent or partially equivalent terms (Matulewska A, in: Lingua Legis in Translation, Peter Lang Publishing House, 2007) as research methods. The material used for analysis comes from selected German, English and Polish legal acts regulating forest management and maintenance that are considered as corpora for the selection of culturally immersed terminology, namely: (i) the Polish Act on Forests of 28th September 1991 [Ustawa $z$ dnia 28 września 1991 r. o lasach], (ii) Title 16 U.S. Code Chapter 2-National Forests, (iii) Forestry Act 1967, Chapter 10 (the United Kingdom), (iv) German Forestry Act 1975 [Gesetz, zur Erhaltung des Waldes und zur Förderung der Forstwirtschaft (Bundeswaldgesetz) von 1975]. The paper concerns potential problems that could occur in the translation of culturally immersed legal terminology due to the terms' rigidity and high degree of specificity. The studies presented will allow conclusions to be drawn regarding the possibilities and strategies for translating culturally immersed terms. In addition, the availability of terminological dictionaries for these language pairs will be discussed.
\end{abstract}

Extended author information available on the last page of the article 
Keywords Forest $\cdot$ Legal regulatory acts $\cdot$ Specific terminology $\cdot$ Culturally driven . Culturally immersed · Forestry · Poland · The United Kingdom · The United States of America · Germany

\section{Introduction}

Forests have recently been a frequent topic of heated debate on social media. Usually, their focus is on their preservation as natural habitats for numerous species, opposed to the need for industrial development. The increased interest in the subject has led also to increasing interest in forests themselves and the extension of research into the linguistic aspects of forests, which is still a relatively unexplored field.

The translation of legal acts and different regulations concerning forests can play the role of a third space. This new theory about the "third space" was developed by Bhabha (in [3]). He states that "all forms of culture are continually in a process of hybridity", and "the importance of hybridity is not to be able to trace two original moments from which the third emerges, rather hybridity (...) is the "third space' which enables other positions to emerge". According to Wagner [4], we are mostly dealing with two spaces when it comes to legal translation: source and target space. She claims that the process of legal translation constitutes a third space, "a space in-between", "undefined, vague, and fluid", "a precondition for the negotiation, transformation and translation (...) between two cultures", "where mechanisms of transfer, of importation from one culture to another have to be fairly analysed" [4]. This space "in-between" is vague, cannot be touched, is ethereal. It is a space "which enables other positions to emerge and where all forms of cultures are continually in a process of hybridity, of evolution" [3]. Each country has different regulations concerning forests, hence the act of translation of legal acts serves as a crosscultural event. System bound legal concepts and notions are the most problematic elements to render in any target language. It can be really difficult, or in many cases impossible to render $100 \%$ of the sense in the target text or to provide $100 \%$ proper equivalents. Some aspects are "in-between", vague and elusive, and that is the third space-the space where one can find information which cannot be included in the final texts of a translation. Some of these aspects are deeply rooted in language, history, customs, which were passed on to other cultures in a changed way. Moreover, sometimes the etymology of a term is hard to establish. It should be mentioned that a third space is "entwined in the source space and the target space" [4]. It creates a "contact zone" between the source and target languages. Furthermore, "low connectivity results in an increased hybridized discourse with many variants in the target language, leading to intercultural efforts of creations and shifts in meanings" [4].

Our purpose was to follow in the footsteps of Matulewska [5], who adopted a procedure for discovering to what extent the terminology for Polish and English texts are convergent or divergent. The translator's choice of an equivalent is of crucial importance when rendering meaning, and what is more the role of our receiver cannot be omitted here.

The following paper aims at filling the existing research gap in the field of interculturally rooted differences in forest related terminology and possible translation 
options. Thus, the contribution concentrates on analyzing forest related terms from legal acts adopted in Germany, the United Kingdom, the United States of America and Poland, e.g. (i) the Polish Act on Forests of 28th September 1991 [Ustawa z dnia 28 września 1991 r. o lasach], (ii) Title 16 U.S. Code Chapter 2-National Forests, (iii) Forestry Act 1967, Chapter 10 (the United Kingdom), (iv) German Forestry Act 1975 [Gesetz zur Erhaltung des Waldes und zur Förderung der Forstwirtschaft (Bundeswaldgesetz) von 1975] and identifying the semantic differences and their culturally rooted origins. These countries differ not only from the environmental point of view (different species structure of dominant tree stands), but also in respect to the ownership structure (e.g. private and state/national forests), which is the result of a different, historical approach to forest use and the development of e.g. the timber industry. This in turn determines quite different legal rules binding in a given country. The conducted analysis aims to find existing equivalent terms in these four languages, as well as to suggest adequate strategies for translation of such terms.

The following paper consists of two main parts: theoretical and empirical. The first part is dedicated to the presentation of legal acts related to forests and their functioning in Germany, the United Kingdom, the United States of America and Poland. Next, the applied research material and methodology are described. The empirical part contains the analysis of selected terms in British English, American English, German and Polish. Furthermore the main problems and possible translation strategies are discussed.

\section{Research Material}

The material used for the analysis comes from the selected German, English and Polish legal acts regulating forest management and maintenance, which are considered as corpora for the selection of culturally immersed terminology, namely:

i. The Polish Act on Forests of 28th September 1991 [46],

ii. Nature Conservation Act (Dz. U. from 2004, No. 92, item 880),

iii. Title 16 U.S. Code Chapter 2-National Forests [47],

iv. Antiquities Act of 1906,

v. Forestry Act 1967, Chapter 10 (the United Kingdom) [48],

vi. National Forest Management Act of 1976,

vii. German Forestry Act 1975 [Gesetz zur Erhaltung des Waldes und zur Förderung der Forstwirtschaft (Bundeswaldgesetz) von 1975], in the administrative structure of Germany there are separate acts adopted at the level of Bundesländer (states) for example Waldgesetz des Landes Brandenburg (LWaldG) ${ }^{1}$

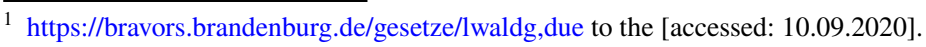




\section{Research Methods}

The authors used two main research methods apart from the contrastive analysis of the materials. The first method is based on the categories of equivalence proposed by Šarčević [1] and the second one is based on the techniques of providing equivalents for non-equivalent or partially equivalent terminology by Matulewska [5]. The first methodthe analysis of terminology according to three categories of equivalence as determined by Šarčević [1]: "near equivalence", "partial equivalence" and "non-equivalence", where "near equivalence" occurs "when concepts A and B share all of their essential and most of their accidental features (intersection) or when concept A contains all of the characteristics of concept B, and concept B all of the essential and most of the accidental characteristics of concept A (inclusion)" [1]."Partial equivalence" appears when concepts A and B share most of their essential and some of their accidental features (intersection) or when concept A includes all of the characteristics of concept B but concept B only has most of the essential and some of the accidental characteristics of concept A (inclusion). When only a few or none of the essential characteristics of concepts A and B coincide (intersection), or when concept A has all of the characteristics of concept B but concept B only has a few or none of the characteristics of concept A (inclusion) "non-equivalence" occurs and the functional equivalent is considered as unacceptable [1].

The techniques of providing equivalents for non-equivalent or partially equivalent terminology have been discussed over several decades (cf. [2, 6-11]). When looking for equivalents the following techniques may be considered:

(i) different types of borrowings:-loanwords,--loanblends,--loanshifts (calques),- - hybrids,- - exotics, - international terms,

(ii) definitions and other types of descriptive equivalents,

(iii) neologisms,

(iv) expansion,

(v) restriction,

(vi) two terms or more for one,

(vii) cultureless descriptive and Latin-based terms,

(viii) unassimilated Latin terms,

(ix) functional equivalents,

(x) modified functional equivalents, and.

(xi) antonyms (cf. [5]).

However, not all of them have been applied to the terminology in question. This is due to the fact that a limited number of terms are discussed here, and the techniques which have been used include descriptive equivalents and modified functional equivalents.

\subsection{Forests in Poland in Brief}

Polish forests cover about $30 \%$ of Poland's territory, and are mostly owned by the state $(81.8 \%)$, the majority $(77.8 \%)$ by Polish State Forests (Lasy Państwowe), $2 \%$ constitute Polish National Forests protected zones, $2 \%$ are owned by other 
governmental entities (such as local government or the Agricultural Property Agency) and $18.2 \%$ belong to private owners [12].

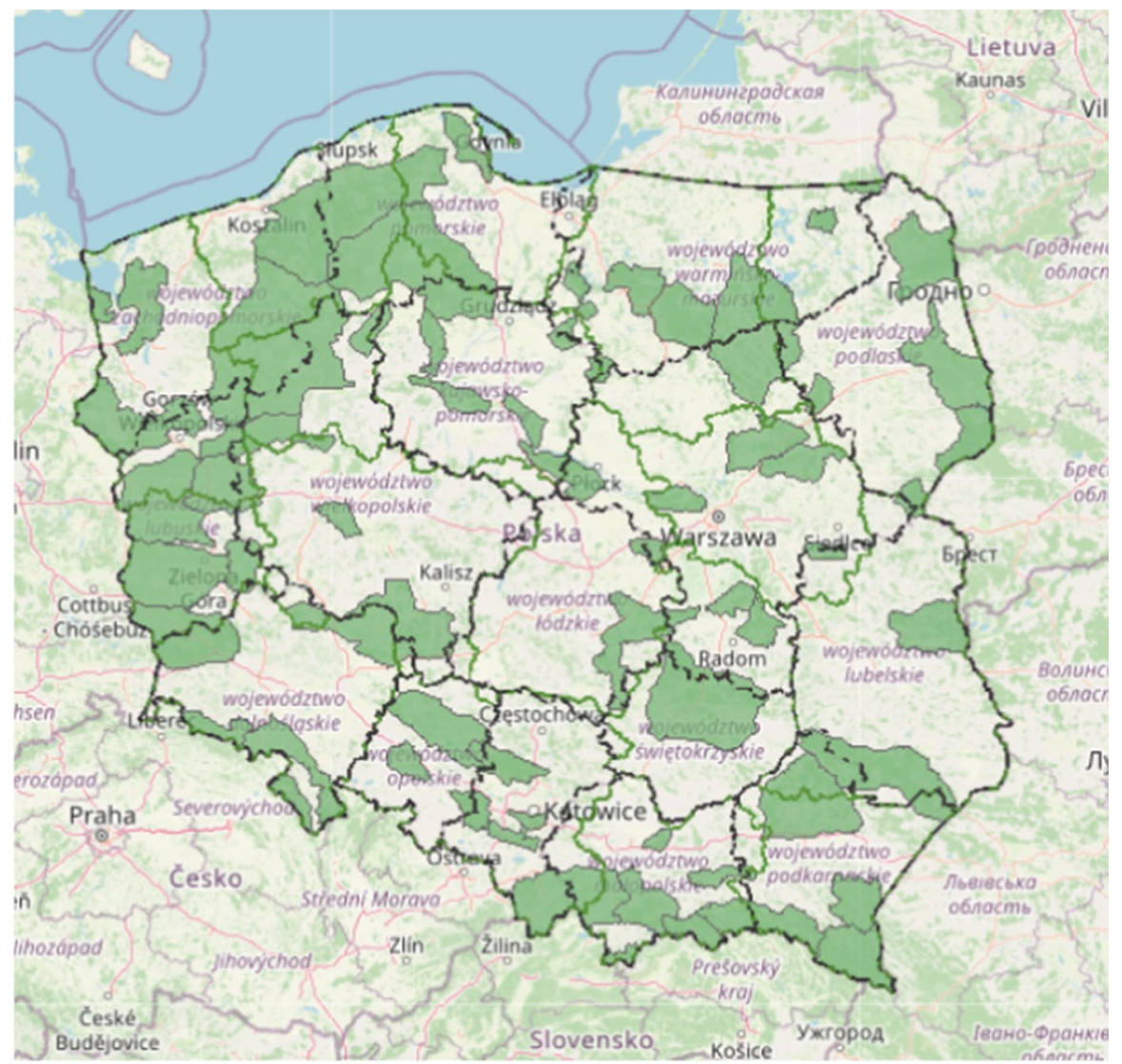

The map of Polish Forests (Puszcze w Polsce) Retrieved from https://www. bdl.lasy.gov.pl/portal/mapy? $\mathrm{t}=0 \& 1 \mathrm{l}=19.412949,52.001221 \&$ scale $=46223$ $24 \&$ map $=0,0.7 \&$ layers $=0,1,2,3,4,5,8,9,10,11,12,14,15,16,17$ \&basemap $=2 \&$ extwm $\mathrm{s}=$ \&hist $=$

Historically, the forest area was bigger compared to today's figures. At the end of the eighteenth century, forests covered around $40 \%$ of Poland which is $10 \%$ more than today. However, the partitions of Poland that happened at the turn of eighteenth and nineteenth centuries, as well as the Nazi German and Soviet occupations between 1939-1945 led to deforestation. After the war, the amount of forest area shrank to $21 \%$. Moreover, trees of good quality were replaced with fast growing trees of lesser value. After World War II, the government of Poland initiated the National Plan of Afforestation. By 1970, forests covered $29 \%$ of the country [12]. As of 2009-29.1\% of Poland's territory was forested, amounting to $9,088,000$ hectares [12]. It is estimated that by 2050 , the total area of forested land should increase to $33 \%$ [12]. 


\subsection{Forests in Germany in Brief}

Forest and its presence is deeply rooted in German cultural consciousness. Forests cover eleven million hectares in Germany. That is almost one third of the country's area.

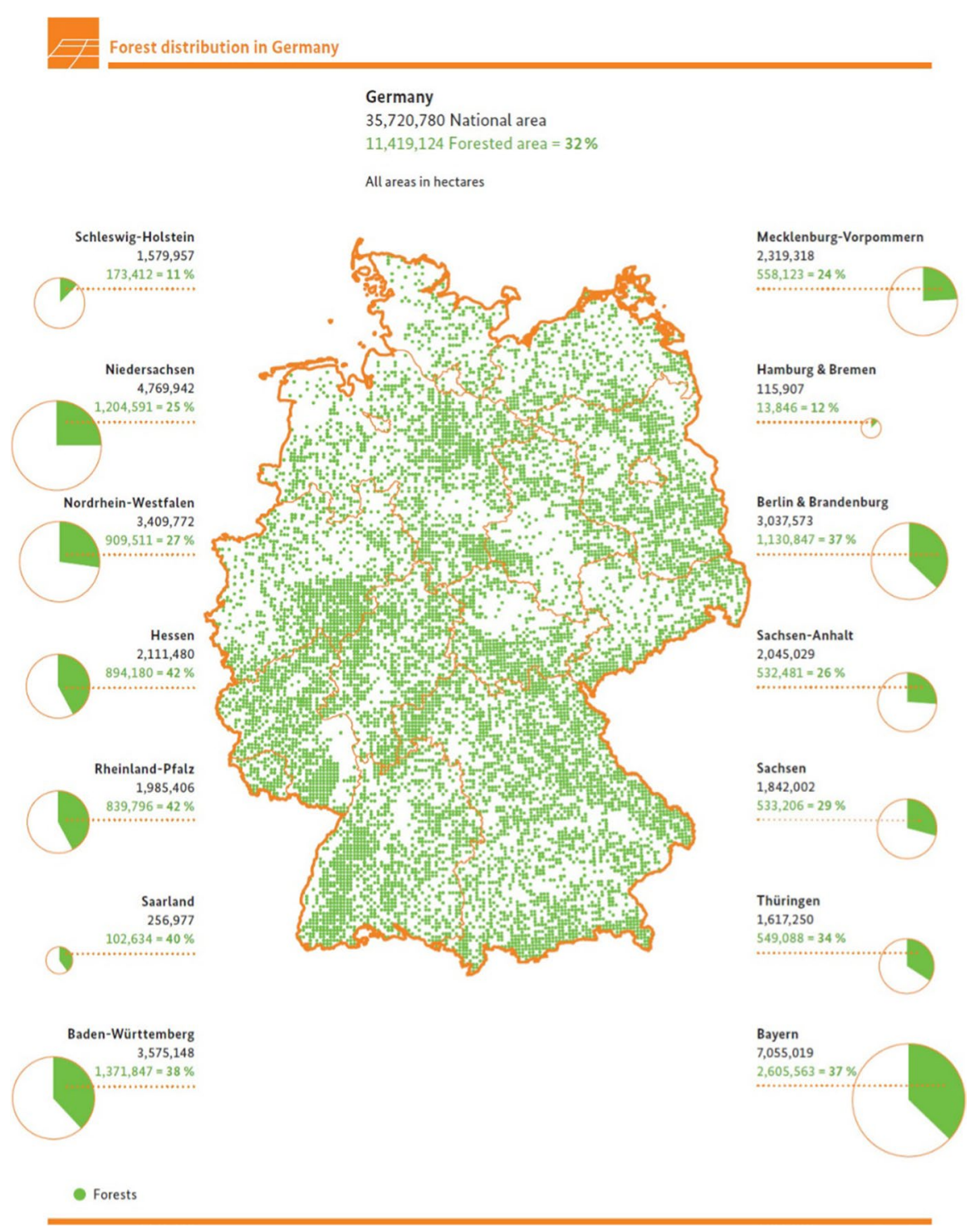

The map of German Forests

Retrieved from https://www.bundeswaldinventur.de/fileadmin/SITE_MASTER/ content/bilder/BWI3/ForestDistribution.jpg 
In Germany, the natural conditions are similar to those in Poland but the existing differences concern, in particular, the organizational forms of the management of forests and "forest" ownership structures. In most federal states, state forests are subject to regional forest offices, which consist of individual forest districts ranging from 1500 to 3000 ha. The districts are managed by foresters. The tasks of the forest offices include the management of real estate, as well as economic management of forests. Public forests in Germany are state and municipal property, whereby state ownership extends to forests in the certain states (Bundesländer) and federations. Forest management issues are governed by the provisions of trade union law and the regulations of the individual states [13]. In accordance with the German Constitution, Federal law in Germany takes precedence over national law [14].

The Bundesländer in Germany also have the status of "states". Between the Länder and the Federation there is a constitutional division of competences (Article 70(2)). Legislation covers competitive competencies. Under Basic Law, the administration of forestry falls within the competence of the Länder, which is why there are as many as 16 'entities' in Germany carrying out these functions.

\subsection{Forests in the UK and the USA in Brief}

Compared to Poland and Germany, the UK's forest area is much smaller. About $12.9 \%$ of Britain's land surface is wooded. Similarly to Poland, the country's supply of timber was severely depleted during both World Wars. In 1919, the Forestry Commission [15] was established to produce a strategic reserve of timber [16-18] (Fig. 1).

Around $30 \%$ of the forest area in Britain is publicly owned and $70 \%$ is in the private sector. The interesting thing is the fact that in 2010 the government of the UK suggested it might sell off around half the Forestry Commission-owned woodland in the UK. But the idea was abandoned a year later. Instead, the government took some actions to increase the amount of woodlands in the UK.

The United States has 154 protected areas known as National Forests, covering $188,336,179$ acres $\left(762,169 \mathrm{~km}^{2} / 294,275\right.$ sq. mi) [19]. The National Forests are managed by the U.S. Forest Service, an agency of the U.S. Department of Agriculture [20]. The first National Forest was established in Yellowstone, as the Yellowstone Park Timber and Land Reserve in 1891. A couple of years later, in 1897, the Organic Act set out the purposes for which forest reserves could be established, including to protect the forest, secure water supplies, and supply timber. What is more, thanks to the Forest Reserve Act of 1891, the President of the United States was given the power to set aside forest reserves in the public domain. However, with the Transfer Act of 1905, forest reserves became part of the U.S. Department of Agriculture in the U.S. Forest Service [21, 22].

Apart from forest lands, there are additional land areas which include 20 National Grasslands, 59 purchase units, 19 research and experimental areas, five land utilization projects and 37 other areas. There are currently 154 named National Forests (many of these are managed together as either a single forest or separate forests) [23] (Fig.2). 
It is necessary to clarify here what constitutes a national grassland, and what are the main differences between National Forest and National Grassland. National Grassland is a classification of protected and managed federal lands authorized by Title III of the Bankhead-Jones Farm Tenant Act of 1937. For administrative purposes, they are essentially identical to United States National Forests, except that grasslands are areas primarily consisting of prairie. Like National Forests, National Grasslands may be used for hunting, grazing, mineral extraction, recreation and other functions. Various National Grasslands are typically administered in conjunction with nearby National Forests. Whereas a typical National Forest would be about 1,000,000 acres (400,000 ha), the average Grassland size is 191,914 acres (77,665 ha). The largest National Grassland is approximately the median size of a National Forest [19].

\section{Selected Terminology}

In this section the authors will analyse selected terminology connected with forest law and some cultural aspects will be mentioned as well. The main point, however, is to conduct a contrastive translational analysis of key terms in four different languages, that is to say Polish, German and two variants of English (British and American). The main task is to evaluate the equivalence correspondence and check whether the terms are near equivalents, partial equivalents or non-equivalent according to the categories provided by Šarčević [1]. For the purpose of analysis the authors chose eight terms: the most important ones for this category, and at the same time the most general ones (1) forest, (2) Public Forests, (3) Recreational Forest, (4) national parks, (5) forest management, (6) Forest Valuation, as well as (7) Promotional Forest Complex and (8) Forest Service. At the end of each term the authors analyse the level of equivalence, and if there is no equivalence they provide new terms using techniques for providing equivalents for non-equivalent terms [5].

\subsection{Forest-Wald-Las}

Forest is a unique place, extremely diverse in terms of biodiversity and culture, which depends on both changes in history and the geographical region. In this context, scientists dealing not only with forest sciences have a problem with the unequivocal definition of the term "forest". There are over 100 definitions in the literature. For example, Karpiński [53] defines a forest (forest biocenosis) as.

A dynamic natural formation in which dependencies, links and mutual influences are combined into an indivisible whole: a specific vegetation with a predominant share of woody forms, associated animals and the geological substratum used by plants and animals, soil, water and climate.

However, if we assume that the main characteristic of a forest is the fact that it has trees, it turns out that the definition in the Polish Act on forests mentions that a 


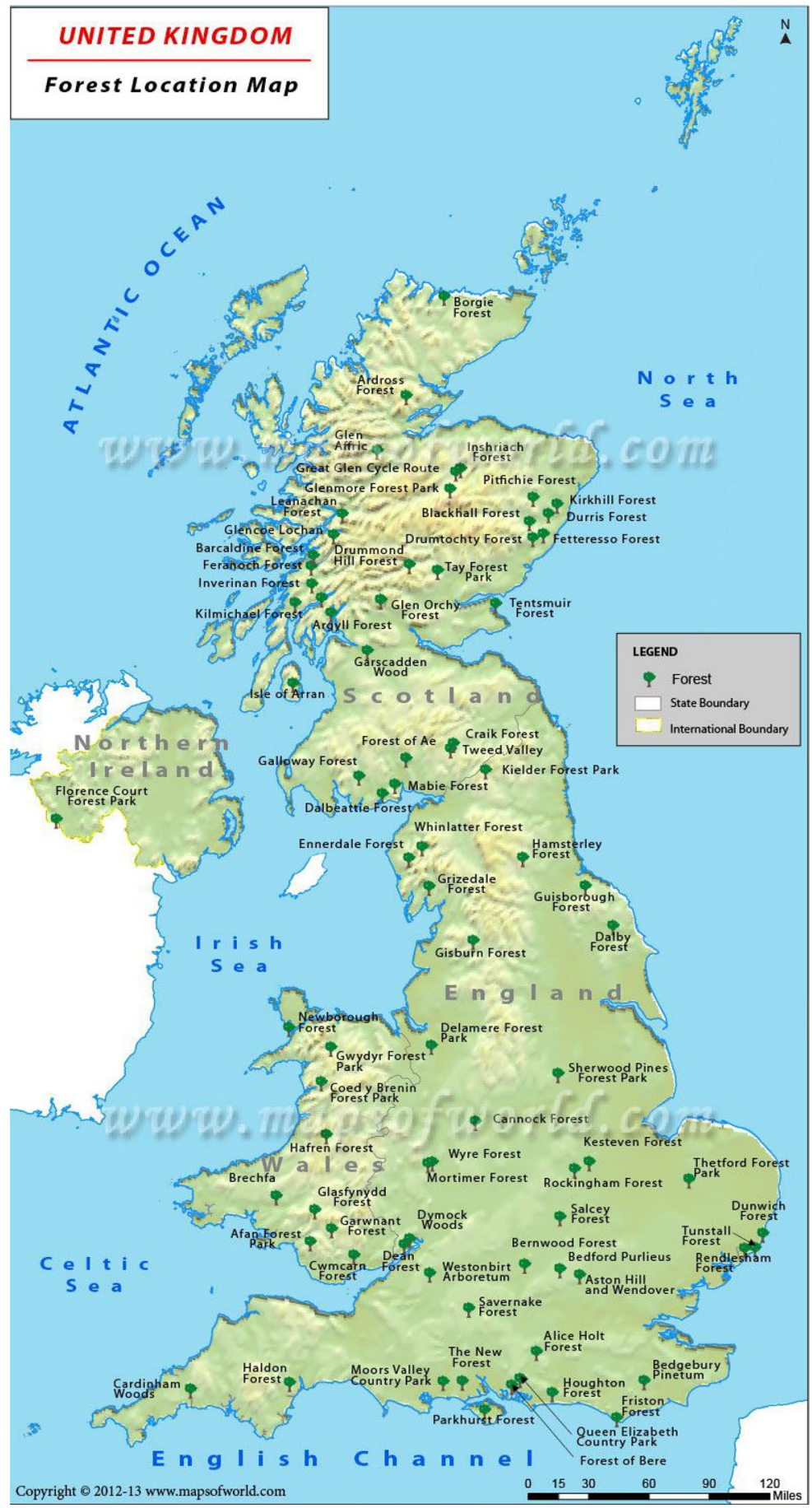

Fig. 1 UK forest location map. Retrieved from: https://i.pinimg.com/originals/54/32/17/543217344c 4a6b92c7da8074d2cce6b2.jpg 


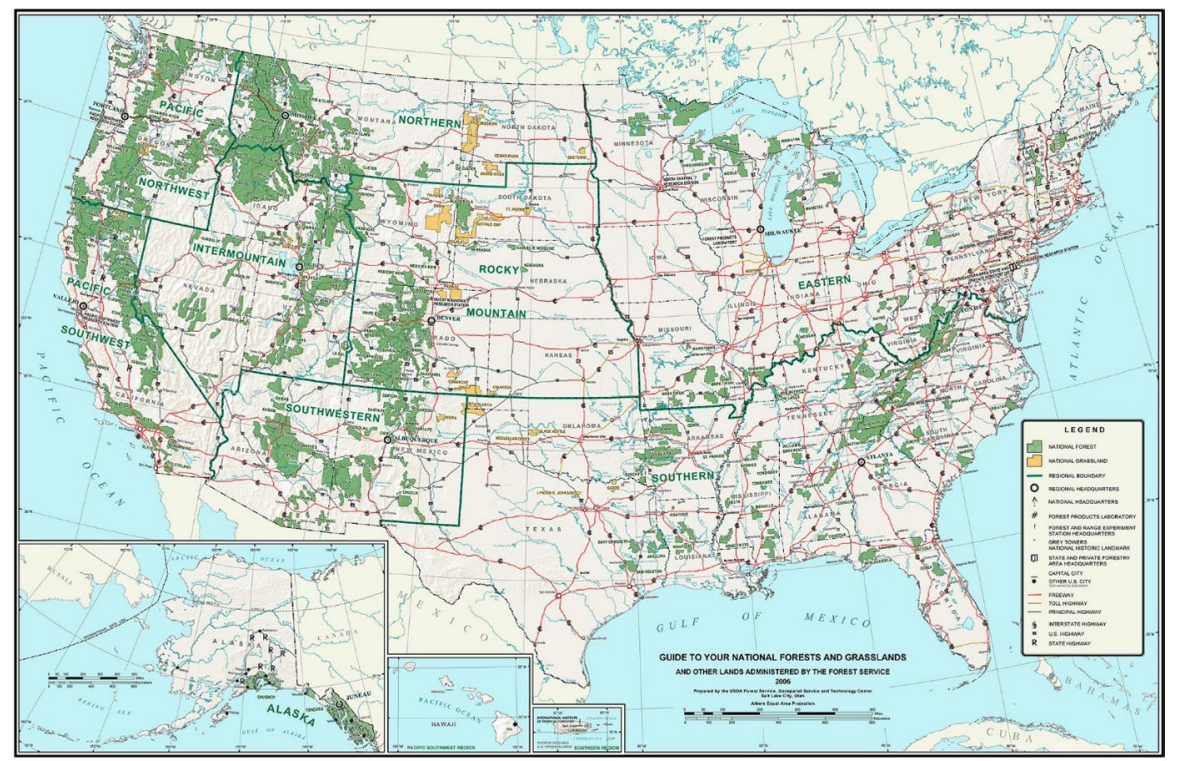

Fig. 2 US national forests. Picture retrieved from: https://en.wikipedia.org/wiki/List_of_U.S._National_ Forests

forest may be an area temporarily devoid of trees. If we also add linguistic issues, e.g. wood (a dense growth of trees or underbrush covering a relatively small or confined area) and forest (a dense growth of trees, plants, and underbrush covering a LARGE area), the complexity of the analyzed problems is clearly visible.

The word forest is the basic term in relation to the described topic, it also occurs in legislative acts in the discussed countries. Although the word "forest" corresponds with the term Wald in German, the relationship from a legal perspective between these terms is not clear. It is worth analyzing here the definitions given by the legislator (Table 1).

The definition in German is clearly more general and wider, among other things without any indication of a minimum forest area, which is clearly stated in the Polish definition. While in Poland a forest is considered to be entirely or partly forested, in Germany it can also include cleared areas, forest roads, forest districts and protection strips, palm trees and forest clearings, forest meadows, pasture if it is related to forest activity. In addition, it is worth pointing out the cultural value of the forest in the Polish tradition, which is clearly included in the legal definition, namely the treatment of areas included in the list of monuments as forest. In the German legal act, apart from the definition of Wald there is also a restriction of what cannot be defined as Wald. For the purposes of this Act, the following are not forest:

1. areas where tree species are planted with the aim of early harvesting and where the trees have a rotation period of no more than 20 years (short rotation plantations), 
2. areas planted with trees which are also used for growing agricultural products (agroforestry use),

3. areas planted with forest plants, which on 6 August 2010 are recorded as agricultural land in the area identification system referred to in the first sentence of Sect. 3 of the IACS Regulation of 3 December 2004 (Federal Law Gazette I p. 3194), as last amended by Article 2 of the Regulation of 7 May 2010 (eBAnz AT51 $2010 \mathrm{V1}$ ), as long as their agricultural use continues and.

4. smaller areas located in the field or in a built-up area, planted with individual groups of trees, rows of trees or hedges or used as nurseries.

What is also worth mentioning is that the final decision concerning the classification of certain surfaces as forest belongs to the certain states (Bundesländer) which can create further discrepancies in the respective meaning linked to the word Wald.

Pursuant to 25 USCS $\S 3103$ (2) [25], the term forest means "an ecosystem of at least one acre in size, including timberland and woodland, which:

(A) is characterised by a more or less dense and extensive tree cover,

(B) contains, or once contained, at least ten percent tree crown cover, and.

(C) is not developed or planned for exclusive nonforest use."

It can be easily noted that in terms of size the American term can be related to the Polish term, not to the German one.

Moreover, according to 7 CFR 625.2 [26], forest ecosystem means "a dynamic set of living organisms, including plants, animals, and microorganisms interacting among themselves and with the environment in which they live. A forest ecosystem is characterized by predominance of trees, and by the fauna, flora, and ecological cycles (energy, water, carbon, and nutrients)."

In America there are different types of forests and they are defined by different legal documents, not only by the above mentioned legal acts. For example, pursuant to 16 USCS § 6703 (3) [27] the term dry forest and woodland ecosystem means "an ecosystem that is dominated by ponderosa pines and associated dry forest and woodland types." The ecosystem in the USA is very varied, and it is hard to establish a single definition which will be as narrow as the Polish or German definitions of a forest.

In old English law a forest means "a certain territory of wooded ground and fruitful pastures, privileged for wild beasts and fowls of forest, chase, and warren, to rest and abide in the safe protection of the prince for his princely delight and pleasure, having a peculiar court and officers" [28]. What is more, according to Spelman and Cowell, a forest is "A royal hunting-ground which lost its peculiar character with the extinction of its courts, or when the franchise passed into the hands of a subject". The word forest is also used to signify a franchise or right, being the right of keeping, for the purpose of hunting, the wild beasts and fowls of forest chase, park, and warren, in a territory or precinct of woody ground or pasture set apart for the purpose [29]. In the Forest law, according to Cowell, a forest is "The system or body of old law relating to the royal forests". However, thanks to the Study on European Forestry Information and Communication System [52] we know that the forests 


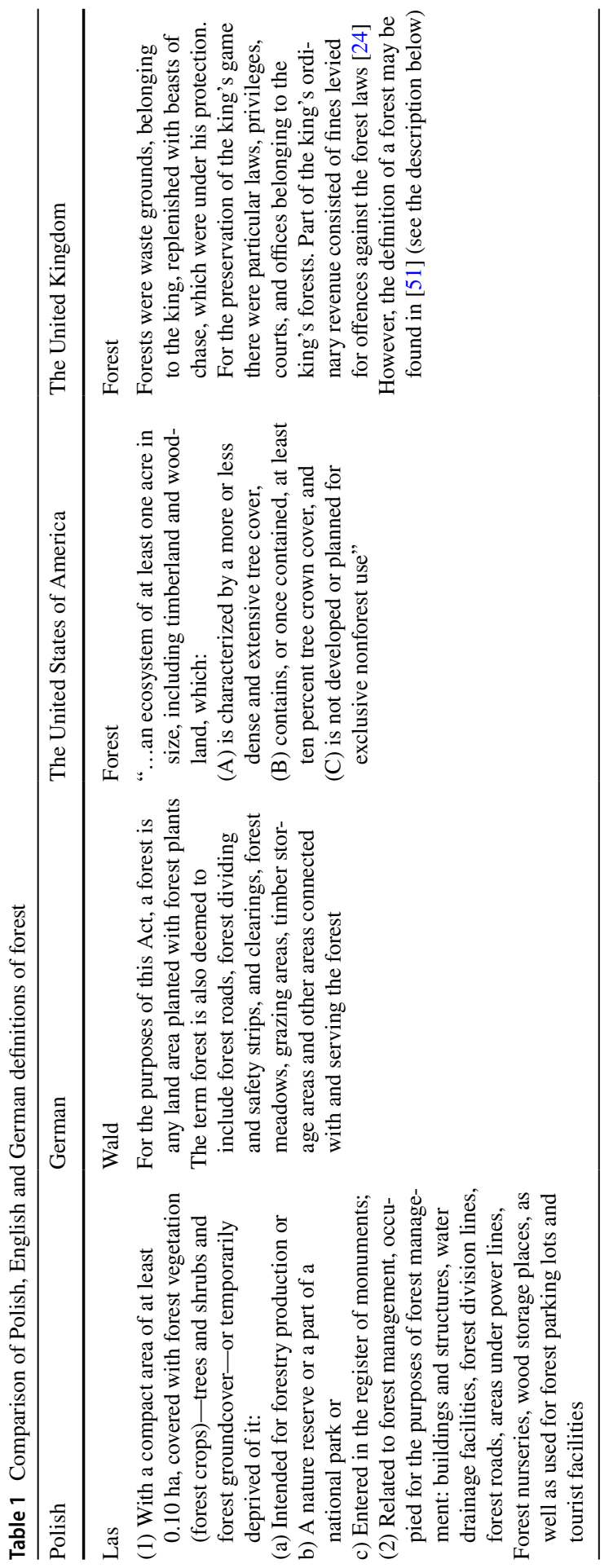


in the UK have to cover minimum area of 2 ha; in general its minimum width is $50 \mathrm{~m}$; areas of scattered trees with distinct crowns constitute woodland if the canopy covers more than $20 \%$ of the ground. Areas of young trees which have the potential to achieve a canopy cover of more than $20 \%$ are also interpreted as woodland. Scrub will be included under its predominant photo-interpreted forest type (Conifer, Broadleaf, Mixed) or if not easily differentiated in this way it may be classed as Shrub land. Woodland also includes areas that may temporarily be without tree cover following forest operations such as felling cf. 51].

The parametric approach according to Trzaskawka [50] was taken. It is clearly visible in the table below that the term forest and its definition in Polish, German, American and British is not a near equivalent according to Šarčević [1]. Inside the definition of a "forest" in each country there are numerous parameters which are not present in the other countries. It can be seen that the only parameter where there is $100 \%$ equivalence is the one which speaks about the area being covered by trees. In terms of the size of a forest, the Polish, American and British terms may be partially equivalent, as the Polish and American terms are hyponymous toward the British one. The German definition does not provide any information about the size of a forest. It means that here we have the phenomenon of a non-equivalent term compared with the Polish, American and British terms. The other features of the term forest in the above mentioned languages are of partial or non-equivalent value.

According to Bhabha's theory, we can distinguish two categories of meanings: common meanings and in-between meanings. As for the term forest it can have a common meaning among lay persons, but for a specialist or a forester the term forest is only partially equivalent, hence occupying the space "in-between" as he calls it. It can be said that in this case the "in-between" meaning lies in the exact definitions of terms. Something which may on first sight look like a near equivalent after a further look reveals that the equivalence is not present. To show more clearly the term forest the best way is to give the whole definition behind it. Of course, first we have to take into account the receiver of the message and focus the target message on him/her. Also, the context, when, where and why affects the choices of our translation. 


\begin{tabular}{l} 
area of at least 0.10 ha \\
\hline at least one acre in size $(0.40$ ha) \\
minimum area 2 ha \\
minimum width is $50 \mathrm{~m}$ \\
\hline contains at least $10 \%$ tree crown cover \\
canopy covers more than $20 \%$ of the \\
ground \\
area covered with forest vegetation \\
area temporarily deprived of trees \\
\hline intended for forestry production \\
\hline a nature reserve \\
\hline a part of a national park \\
entered in the register of monuments \\
related to forest management \\
forest nurseries \\
wood storage places \\
forest parking lots \\
forest roads \\
tourist facilities \\
forest meadows \\
grazing area \\
\hline not developed or planned for exclusive \\
non forest use
\end{tabular}

\begin{tabular}{|c|c|c|c|}
\hline $\begin{array}{l}\text { Polish } \\
\text { las }\end{array}$ & $\begin{array}{c}\text { German } \\
\text { Wald }\end{array}$ & $\begin{array}{c}\text { American } \\
\text { forest }\end{array}$ & $\begin{array}{l}\text { British } \\
\text { forest }\end{array}$ \\
\hline \multicolumn{4}{|l|}{$\checkmark$} \\
\hline & & $\checkmark$ & \\
\hline & & & $\checkmark$ \\
\hline & & & $\checkmark$ \\
\hline & & $\checkmark$ & \\
\hline & & & $\checkmark$ \\
\hline$\checkmark$ & $\checkmark$ & $\checkmark$ & $\checkmark$ \\
\hline$\checkmark$ & $\checkmark$ & & $\checkmark$ \\
\hline \multicolumn{4}{|l|}{$\checkmark$} \\
\hline \multicolumn{4}{|l|}{$\checkmark$} \\
\hline \multicolumn{4}{|l|}{$\checkmark$} \\
\hline \multicolumn{4}{|l|}{$\checkmark$} \\
\hline \multicolumn{4}{|l|}{$\checkmark$} \\
\hline \multicolumn{4}{|l|}{$\checkmark$} \\
\hline$\checkmark$ & $\checkmark$ & & \\
\hline \multicolumn{4}{|l|}{$\checkmark$} \\
\hline$\checkmark$ & $\checkmark$ & & \\
\hline \multicolumn{4}{|l|}{$\checkmark$} \\
\hline & $\checkmark$ & & \\
\hline & $\checkmark$ & & \\
\hline & & $\checkmark$ & \\
\hline
\end{tabular}

After taking into account the parametric approach by Trzaskawka [50] it can be clearly seen from the table that in the German act there is no information about the size of a forest, as mentioned in the Polish, American and British acts and related documents. It can be stated that in terms of the area covered with forest vegetation all the countries have such a definition inside a term "forest" (we have $100 \%$ equivalence). There are some features which are present only in one country-then we are dealing with non-equivalence. To sum up, because of some discrepancies between the terms, it can be stated that all the terms-Polish, German and English are partial equivalents according to Šarčević.

\subsection{Lasy Państwowe-Landeswald, Körperschaftswald and Privatwald—Public Forests}

\begin{tabular}{llll}
\hline Polish & German & The United States of America & The United Kingdom \\
\hline Lasy państwowe & $\begin{array}{l}\text { Staatswald/Landeswald } \\
\text { Körperschaftswald } \\
\text { Privatwald }\end{array}$ & Public forests & Public forests \\
& & & \\
\hline
\end{tabular}

In the German legislation there is the following administrative tripartite division of forest in reference to its owner: Landeswald, Körperschaftswald and Privatwald. 
1. Staatswald/Landeswald (State Forest) is forest which is solely owned by a certain state, for example Brandenburg.

2. Körperschaftswald (Corporate Forest) is forest which is solely owned by towns and municipalities, associations of municipalities, special purpose associations and other corporations, institutions or foundations under public law.

3. Privatwald (private forest) is forest owned by religious communities and their institutions, as well as forest which is not state forest or corporate forest. ${ }^{2}$

The following division provides certain translational difficulties, since the legal visions of forest ownership in Poland and Germany are not compatible. These terms can be translated only in a descriptive manner. However, the terms Landeswald and Lasy Państwowe are near equivalents.

In the USA "Eastern forests cover about 384 million acres $(1,550,000 \mathrm{~km} 2)$ and are predominantly broadleaf (74\%), with the exception of extensive coniferous forests and plantations in the southern coastal region. These are largely in private ownership (83\%). By contrast, about 363 million acres $(1,470,000 \mathrm{~km} 2)$ of western forests are predominantly coniferous (78\%) and in public ownership (57\%). Nearly ten million private individuals own about 422 million acres $(1,710,000 \mathrm{~km} 2)$ of forest and other wooded land. Most public forest land is held by four Federal agencies (United States Forest Service, Bureau of Land Management, National Park Service, Fish and Wildlife Service) as well as numerous state, county, and municipal government organizations."

In England, The Forestry Commission, which is a non-ministerial government department, is responsible for the management of publicly owned forests, and the regulation of both public and private forestry. 30\% of forests are in public and $70 \%$ are in private hands. Compared to the German definition, the British one is narrower, like in American and Polish, where we can distinguish only two types of forest: public and private. However, the equivalence between all those terms is near.

\begin{tabular}{|c|cccc} 
& $\begin{array}{c}\text { Polish } \\
\text { Lasy Państwowe }\end{array}$ & $\begin{array}{c}\text { German } \\
\text { Staatswald/Landeswald }\end{array}$ & $\begin{array}{c}\text { American } \\
\text { Public Forests }\end{array}$ & $\begin{array}{c}\text { British } \\
\text { Public Forests }\end{array}$ \\
\hline Public forests & $\checkmark$ & $\checkmark$ & $\checkmark$ & $\checkmark$ \\
& & & &
\end{tabular}

As from the analysis above, it can be stated that the term public forest is a near equivalent. Such a type of forest is present in each country, hence the translator can use the terms Lasy Państwowe, Landeswald and Public Forests as near equivalents according to Šarčević.

As for Bhabha's third space theory and interpretation, the core meaning in each language is the same, so we can talk about a common meaning here (the term public forest works as a common space in each discussed language). The interlingual

\footnotetext{
2 andesrecht.rlp.de/jportal/portal/t/hmc/page/bsrlpprod.psml; jsessionid $=$ FDF1751593873E589089EF70FD3C9C31.jp28?pid $=$ Dokumentanzeige $\&$ showdoccase $=1 \&$ js_peid $=$ Trefferliste $\&$ fromdoctodoc $=y$ es \&doc $\cdot$ id $=$ jlr-WaldGRPpG11\&doc $\cdot$ part $=$ X\&doc $\cdot$ price $=0.0 \&$ doc $\cdot h l=0 \# j$ lr-WaldGRPpP2.
} 
communication lies between the systemic and historical approaches towards forests in each country. However, one basis is established, as each country has a concept of private and public forests.

\subsection{Erholungswald-Recreational Forest-lasy ochronne}

In the German legislation the term Erholungswald appears, which is referred to as:

Recreational forest is a forest in conurbations, near towns and larger settlements as part of municipalities, and in recreational areas around health resorts, which must be specially protected, maintained and designed for recreational purposes. Translation JK-D. ${ }^{3}$

Erholungswald is a phenomenon that is deeply rooted in the German tradition, which we can find in the description of one of the Erholungswälder ${ }^{4}$ :

The famous landscape architect Peter Joseph Lenne left the old aisles in place and opened up the area with additional paths. The avenues are still clearly visible today. Light pine forests were supplemented with hardwood species. Since its redesign in the nineteenth century, the game park has been a popular destination in the west of Potsdam. From the middle of the 19th to the middle of the twentieth century, residence in the park was reserved for the inhabitants of the adjacent palaces for hunting and amusement.

This phenomenon exists in Polish legislation as well. According to the Polish Act on Forests, art. 15, par. 7 lasy ochronne (lit. protective forests) are forests which are located: (a) within the administrative borders of cities and within $10 \mathrm{~km}$ from the administrative borders of cities with over 50,000 inhabitants, (b) in protection zones of health resorts and health resort protection areas within the meaning of the Act of 28 July 2005 on spa treatment, health resorts and spa protection areas and on spa communes (Dz. U. of 2012, items 651 and 742 and of 2015, item 1844) or c) in the upper forest border zone.

As there are no equivalents (non-equivalence according to Šarčević [1]) in the English legal acts we have to create new equivalents. According to the German definition in English (both variants) it could be a recreational forest.

\footnotetext{
${ }^{3}$ Erholungswald ist Wald in Ballungsräumen, in der Nähe von Städten sowie größeren Siedlungen als Teil von Gemeinden und in Erholungsgebieten um Kurorte, der zum Zwecke der Erholung besonders zu schützen, zu pflegen und zu gestalten ist.

4 „Der berühmte Gartenarchitekt Peter Joseph Lenne' ließ alte Schneisen bestehen und erschloss das Gelände durch weitere Wege. Die Alleen sind heute noch gut erkennbar. Lichte Kiefernwälder wurden mit Laubholzarten ergänzt. Der Wildpark stellt für den Potsdamer Westen seit seiner Umgestaltung im 9. Jahrhundert ein wilkommenes Ausflugsziel dar. Seit Mitte des 19. bis zur Mitte des 20. Jahrhunderts war der Aufenthalt im Wildpark den Bewohnern der anliegenden Schlösser zum Zwecke der Jagd und des Vergnügens vorbehalten".

https://forst.brandenburg.de/lfb/de/struktur/oberfoerstereien-behoerde/oberfoersterei-potsdam/erhol ungswald-wildpark/ 05.09.2020.
} 


\begin{tabular}{|c|c|c|c|c|}
\hline & $\begin{array}{c}\text { Polish } \\
\text { lasy } \\
\text { ochronne }\end{array}$ & $\begin{array}{c}\text { German } \\
\text { Erholungswald }\end{array}$ & $\begin{array}{l}\text { American } \\
\text { Recreational } \\
\text { Forest }\end{array}$ & $\begin{array}{c}\text { British } \\
\text { Recreational } \\
\text { Forest }\end{array}$ \\
\hline $\begin{array}{c}\text { forests near towns or larger } \\
\text { settlements }\end{array}$ & $\checkmark$ & $\checkmark$ & & \\
\hline located in/near health resorts & $\checkmark$ & $\checkmark$ & & \\
\hline $\begin{array}{l}\text { located in upper forest border } \\
\text { zone }\end{array}$ & $\checkmark$ & & & \\
\hline
\end{tabular}

Taking into consideration the above results we can state that the terms recreational forest in German and lasy ochronne in Polish have no equivalents in English based on what we can learn from the legal acts (non-equivalence according to Šarčević). Nevertheless, the Polish and German terms are near equivalents.

The question here is which type of space of interlingual communication is present according to Bhabha's Third Space theory in the case of recreational forest. This concept is deeply rooted in German culture. Poland, which is a neighboring country, operates with a similar term. However, the interesting thing is the fact that in Polish the terms las ochronny and las rekreacyjny are synonymous for a lay person, but in terms of specialist language the meaning is different. Here, the problem lies in the translator's interpretation. If it is misinterpreted the meaning is not properly transferred to the receiver. Moreover, in the United Kingdom or the USA there is no concept of a recreational forest. This may be caused by historical and cultural differences, and the functions of forests in the past.

\subsection{Nationalpark-Parki narodowe-National Parks}

It is general knowledge that a national park is a park used for conservation purposes, created and protected by national governments. It is very often a reserve of natural, semi-natural, or developed land that a sovereign state declares or owns. Each country designates their own parks differently, but there is a common belief that the conservation of "untamed nature" serves as a symbol of national pride [31].

An international organisation called the International Union for Conservation of Nature (IUCN), and its World Commission on Protected Areas (WCPA), has defined "National Park" as its Category II type of protected areas [32]. The United States established the first "public park or pleasuring-ground for the benefit and enjoyment of the people", Yellowstone National Park, in 1872 [33]. However, at first, Yellowstone was not officially named a "national park" in its establishing law. People name it in such a way only in practice [34]. Moreover, this Park is the oldest national park in the world. Generally, all national parks are almost always open to visitors [35] but sometimes some areas are closed, or hard to reach because of the different specifics concerning terrain, access or danger. 


\begin{tabular}{|c|c|c|c|}
\hline Polish & German & American & British \\
\hline $\begin{array}{l}\text { A national park covers } \\
\text { an area distinguished } \\
\text { by particular natural, } \\
\text { scientific, social, cul- } \\
\text { tural and educational } \\
\text { values, with an area of } \\
\text { not less than } 1000 \text { ha, } \\
\text { where all nature and } \\
\text { landscape values are } \\
\text { protected } \\
\text { A national park is } \\
\text { created in order to } \\
\text { preserve biological } \\
\text { diversity, resources, } \\
\text { creations and com- } \\
\text { ponents of inanimate } \\
\text { nature and landscape } \\
\text { values, to restore the } \\
\text { proper condition of } \\
\text { resources and com- } \\
\text { ponents of nature and } \\
\text { to restore deformed } \\
\text { natural habitats, } \\
\text { plant, animal or fungi } \\
\text { habitats }\end{array}$ & $\begin{array}{l}\text { designated areas } \\
\text { where special protec- } \\
\text { tion of nature and } \\
\text { landscape, either } \\
\text { in their entirety or } \\
\text { in individual parts, } \\
\text { is required for the } \\
\text { conservation, devel- } \\
\text { opment or restoration } \\
\text { of habitats, biotopes } \\
\text { or communities of } \\
\text { certain species of } \\
\text { wild fauna and flora, } \\
\text { for scientific, natural- } \\
\text { historical or regional } \\
\text { reasons, or because } \\
\text { of their rarity, special } \\
\text { character or outstand- } \\
\text { ing beauty } \\
\text { (2) All acts which may } \\
\text { lead to destruction, } \\
\text { damage or alteration } \\
\text { of the nature reserve } \\
\text { or its components or } \\
\text { to lasting disturbance } \\
\text { are prohibited in } \\
\text { accordance with more } \\
\text { detailed provisions. } \\
\text { Where the purpose of } \\
\text { protection so permits, } \\
\text { nature reserves may } \\
\text { be made accessible to } \\
\text { the public }\end{array}$ & $\begin{array}{l}\text {... an area of scenic } \\
\text { beauty, historical and } \\
\text { scientific interest, etc. } \\
\text { maintained and pre- } \\
\text { served by the federal } \\
\text { government for the } \\
\text { public to visit [36] }\end{array}$ & $\begin{array}{l}\text {...an area of countryside } \\
\text { for public use desig- } \\
\text { nated by a national } \\
\text { government as being } \\
\text { of notable scenic, envi- } \\
\text { ronmental, or historical } \\
\text { importance [37] }\end{array}$ \\
\hline
\end{tabular}

In the German legislation, the term Nationalpark functions. Again, comparing it with Polish law, in German there is no indication of the minimal area of a park narodowy, whereas in Polish it is stated as being "of not less than 1000 ha". Nevertheless, the equivalence is near, as most of the definitions correspond with each other as far as the essential and most of the accidental features are concerned.

In the USA, the criteria for the selection of national parks include natural beauty, unique geological features, unusual ecosystems, and recreational opportunities (though these criteria are not always considered together). Also, there are things called "national monuments", which are frequently chosen for their historical or archaeological significance. Fourteen national parks are designated UNESCO World Heritage Sites (WHS) [38], while 21 national parks are designated UNESCO Biosphere Reserves (BR) [39]. The system of National Parks that exists nowadays was created in 1916. President Wilson signed the Organic Act creating the National Park Service. The service was, and still is responsible for protecting the 40 national parks and monuments in the USA. The National Parks System includes areas of historical, cultural, scientific, and scenic importance, such as lake shores, seashores, and 
battlefields, and much more besides. National Parks can only be created by Congress through an act of law. Nevertheless, the President of the USA has the authority under the Antiquities Act of $1906^{5}$ to proclaim national monuments on lands already under federal jurisdiction.

In the United Kingdom, there are fourteen national parks, and one further area with 'equivalent status'. Ten of them can be found in England, three in Wales and two in Scotland. What is really interesting is the fact that these parks are not truly national parks according to the internationally accepted standard of the IUCN [40], but they are areas of outstanding landscape where habitation and commercial activities are restricted. This means that from the legal perspective there is no equivalence between the British and Polish, German, American definitions of National Park, but for the purpose of non-specialist translation the term can be freely used.

To sum up, the German, American and Polish terms are near equivalents. The British term is a non-equivalent term, as in the legal act there is nothing about national parks. However, in vernacular language one can find the term national park, and for the purpose of translation one may use it. What is more, according to the IUCN there are no national parks in the UK, and that is why we cannot fully render a proper translation when translating legal acts.

\begin{tabular}{|c|c|c|c|c|}
\hline & $\begin{array}{l}\text { Polish } \\
\text { parki } \\
\text { narodowe }\end{array}$ & $\begin{array}{c}\text { German } \\
\text { Nationalpark }\end{array}$ & $\begin{array}{l}\text { American } \\
\text { National } \\
\text { Parks }\end{array}$ & $\begin{array}{l}\text { British } \\
\text { National } \\
\text { Parks }\end{array}$ \\
\hline $\begin{array}{l}\text { natural, scientific, social, cultural and } \\
\text { educational values }\end{array}$ & $\checkmark$ & $\checkmark$ & $\checkmark$ & \\
\hline not less than $1000 \mathrm{ha}$ & $\checkmark$ & & & \\
\hline $\begin{array}{l}\text { created to preserve biological } \\
\text { diversity, resources }\end{array}$ & $\checkmark$ & & & \\
\hline to restore deformed natural habitats & $\checkmark$ & $\checkmark$ & $\checkmark$ & \\
\hline statutory legal protection & & & $\checkmark$ & \\
\hline $\begin{array}{l}\text { budget and staff sufficient to provide } \\
\text { sufficient effective protection }\end{array}$ & & & $\checkmark$ & \\
\hline $\begin{array}{l}\text { prohibition of exploitation of natural } \\
\text { resources }\end{array}$ & & & $\checkmark$ & \\
\hline natural beauty & & & $\checkmark$ & \\
\hline unique geological features & & & $\checkmark$ & \\
\hline unusual ecosystems & & & $\checkmark$ & \\
\hline recreational opportunities & & & $\checkmark$ & \\
\hline $\begin{array}{l}\text { areas of historical, cultural, scientific, } \\
\text { and scenic importance, such as lake } \\
\text { shores, seashores, and battlefields }\end{array}$ & & & $\checkmark$ & \\
\hline outstanding landscape & & & & $\checkmark$ \\
\hline $\begin{array}{l}\text { habitation and commercial activities } \\
\text { are restricted }\end{array}$ & & & & $\checkmark$ \\
\hline
\end{tabular}

\footnotetext{
5 The Antiquities Act states that a U.S. President is authorised to declare historic landmarks, historic and prehistoric structures, and other objects of historic or scientific interest that are situated upon the lands owned or controlled by the Government of the United States to be national monuments. Congress also has the power to declare national monuments.
} 
It could be stated that the Polish, German and American terms are types of near equivalence but there is non-equivalence, according to Šarčević, between Polish, German and American with the British term, as there is no legal act describing such a thing as a national park. According to Bhabha's theory, the third space of interlingual communication among national parks occurs here, because national parks do exists in different forms, with different names, and under different legal regulations all over the world, but it should function everywhere as a space which is pleasing to any person, and can be treated here as a third space. The term "space inbetween" should be used for a specialist in a given domain where the equivalence is only partial, but for a layperson the terms in all discussed languages have a common meaning.

\subsection{Waldbewirtschaftung-Gospodarka leśna-Forest Management}

In German forest law the term Wladbewirtschaftung refers to the proper management of forest and maintaining sustainability within the framework of its intended purpose. Interestingly, state legislation is obliged to regulate the obligation for all forest owners to ensure that clear-cut forest areas or cleared forest stands are reforested or supplemented, where natural restocking remains incomplete, unless conversion to another type of use has been approved or is otherwise permissible. Forest management also includes the function of forest as an archive of natural and cultural history, and in the case of parks, gardens and cemeteries, the preservation of historical monuments must be taken into account appropriately [41].

The Polish Act mentions gospodarka leśna in art. 6 of the Act on Forests of 28th September 1991. There, forest management is described as:

forest activities in the field of forest management, protection, maintenance and expansion of forest resources and crops, game management, obtaining-with the exception of purchasing-wood, resin, Christmas trees, stumps, bark, pine needles, game and underground fruit, as well as the sale of these products and implementation of non-productive functions of the forest.

Moreover, the Act puts the sustainability and multifunctionality of forests above economic benefits, but does not burden the state budget with the costs of these activities.

In the British act, the term management of forests appears, which is a near equivalent with the Polish term gospodarka leśna. There is also the term management of forestry land which is more specific compared to the Polish and German term, it is a hyponym, or there is the general term management which works as a hyperonym. In the American act, there is the term forest management which appears 108 times. This is also because there is a special Act called the National Forest Management Act of 1976, which there are references to.

To sum up, all the terms are near equivalents and can be treated as functional equivalents: Polish gospodarka leśna, German Waldbewirtschaftung and English (both variants British and American)_forest management. 


\begin{tabular}{|c|c|c|c|c|}
\hline & $\begin{array}{l}\text { Polish } \\
\text { gospodarka } \\
\text { leśna }\end{array}$ & $\begin{array}{l}\text { German } \\
\text { Waldbewirtschaftung }\end{array}$ & $\begin{array}{l}\text { American } \\
\text { forest } \\
\text { management }\end{array}$ & $\begin{array}{l}\text { British } \\
\text { forest } \\
\text { management }\end{array}$ \\
\hline $\begin{array}{l}\text { proper/effective/sustainable } \\
\text { management of forest }\end{array}$ & $\checkmark$ & $\checkmark$ & $\checkmark$ & $\checkmark$ \\
\hline $\begin{array}{l}\text { maintaining sustainability } \\
\text { within the framework of its } \\
\text { intended purpose }\end{array}$ & $\checkmark$ & $\checkmark$ & $\checkmark$ & $\checkmark$ \\
\hline $\begin{array}{l}\text { regulates the obligation for } \\
\text { all forest owners to ensure } \\
\text { that clear-cut forest areas } \\
\text { or cleared forest stands are } \\
\text { reforested or supplemented }\end{array}$ & $\checkmark$ & $\checkmark$ & $\checkmark$ & $\checkmark$ \\
\hline $\begin{array}{l}\text { functions as an archive of } \\
\text { natural and cultural history }\end{array}$ & & $\checkmark$ & & $\checkmark$ \\
\hline
\end{tabular}

After taking into consideration all the features concerning forest management it could be stated that almost all features are in common and constitute near equivalence in all languages according to Šarčević. According to Bhabha's theory, the terms share common meaning, hence common space.

\subsection{Bonitierungsklasse der Bäume-klasa bonitacji drzewostanu (bonitacja)— Forest Valuation}

This term refers in Polish law to an indicator of the production capacity of a forest habitat and stand, ${ }^{6}$ it functions in German [54] but does not appear in the forest legal act. In English, there exists a term Forest Valuation which means "the comprehensive inventory of a forest and the compilation of a technical description (valuation survey and map) of stands of timber, and the determination of the stands' age, the reserves (quantity) of timber, and the growth and volume of individual trees and parts of trees". However, it does not correspond with the Polish term bonitacja.

To sum up, because in the German legal act there is no such term, we are dealing with non-equivalence. However, for translation purposes, one may use a term which is used in common language, that is to say: Bonitierungsklasse der Bäume. In the English (American and British) acts the situation is the same. The acts do not mention the term Forest Valuation. Moreover, the term that is in usage in vernacular language is not even partially equivalent compared to the Polish term as there are no common features.

\footnotetext{
${ }^{6}$ From the Polish Act: „klasa bonitacji drzewostanu - wskaźnik możliwości produkcyjnej siedliska leśnego i drzewostanu".
} 


\begin{tabular}{|l|l|l|l|}
\hline \multicolumn{1}{|c|}{$\begin{array}{c}\text { Polish } \\
\text { klasa } \\
\text { bonitacji } \\
\text { drzewostanu } \\
\text { (bonitacja) }\end{array}$} & $\begin{array}{c}\text { Gonitierungsklasse } \\
\text { der Bäume }\end{array}$ & $\begin{array}{c}\text { American } \\
\text { Forest } \\
\text { Valuation }\end{array}$ & $\begin{array}{c}\text { British } \\
\text { Faluation }\end{array}$ \\
\hline $\begin{array}{l}\text { an indicator of the production } \\
\text { capacity of a forest habitat } \\
\text { and stand }\end{array}$ & $\checkmark$ & $\checkmark$ & \\
\hline $\begin{array}{l}\text { the comprehensive inventory } \\
\text { of a forest and the compilation } \\
\text { of a technical description } \\
\text { (valuation survey and map) of } \\
\text { stands of timber }\end{array}$ & & & \\
\hline $\begin{array}{l}\text { the determination of the } \\
\text { stands' age }\end{array}$ & & & \\
\hline $\begin{array}{l}\text { the reserves (quantity) of } \\
\text { timber }\end{array}$ & & & \\
\hline $\begin{array}{l}\text { the growth and volume of } \\
\text { individual trees and parts of } \\
\text { trees }\end{array}$ & & & \\
\hline
\end{tabular}

The equivalence between Polish and German in terms of legal acts is zero. However, in other publications and documents one can find the same definition in the German language as in Polish, so here we can say that we are dealing with near equivalence according to Šarčević. In American no such term exists, and in British the term has a completely different meaning from the Polish, hence we have non-equivalence. According to Bhabha's theory, there is space in-between the interlingual communication between Polish and English. In most cases, there are no common meanings. Techniques of providing equivalents for non-equivalent terms should be applied. The best way is to use a descriptive approach, and try to translate bonitacja into an indicator of the productive capacity of the forest habitat. 


\subsection{Leśne kompleksy promocyjne-Waldförderungskomplexe-Promotional Forest Complex}

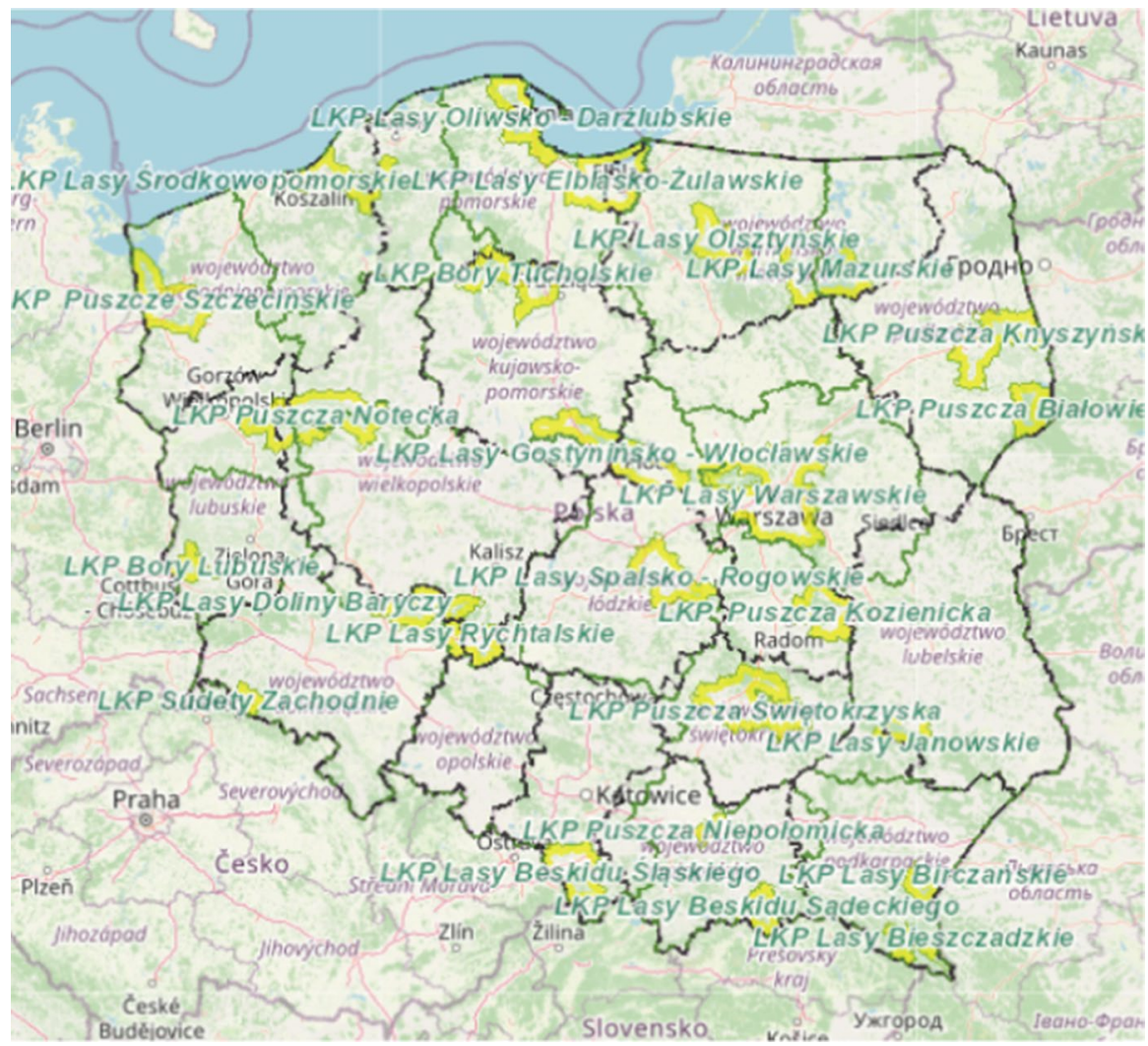

In the Polish legislation, the term leśne kompleksy promocyjne appears, meaning functional areas of ecological, educational and social importance for which activities are defined by a single economic and protection programme, drawn up by the relevant director of the regional directorate. ${ }^{7}$ Such an idea or institution which exists in Poland does not exist in other countries. In German legislation, the term does not appear. However, it can be translated as Waldförderungskomplexe.

Likewise, in both English variants there are no equivalents. There are some narrow terms such as "nordic and alpine ski areas and facilities" or "scenic area" [42], or the term "Scenic Recreation Area" [43] which can work as hyponyms compared

\footnotetext{
${ }^{7}$ According to the Polish Act: ,leśne kompleksy promocyjne są obszarami funkcjonalnymi o znaczeniu ekologicznym, edukacyjnym i społecznym, dla których działalność określa jednolity program gospodarczo-ochronny, opracowywany przez właściwego dyrektora regionalnej dyrekcji Lasów Państwowych.”.
} 
to the Polish term leśne kompleksy promocyjne. For the purpose of the immediate recipient of the text it is best to literally translate and give a definition of what such a term depicts (for example by a gloss). The technique used to establish a proper equivalent is to create a calque. The term may be translated as Promotional Forest Complex.

functional areas of

$\begin{array}{cccc}\begin{array}{c}\text { Polish } \\ \text { Leśne }\end{array} & \text { German } & \begin{array}{c}\text { American } \\ \text { Promotional }\end{array} & \begin{array}{c}\text { British } \\ \text { Promotional } \\$\cline { 4 - 5 } \text {$kompleksy } \\ \text { promocyjne }\end{array}\end{array}$
ecological, educational and social importance

According to Šarčević we deal with non-equivalent terms. To provide such an equivalence, we can use similar concepts used in the vernacular language in each country or create new equivalents according to techniques of providing equivalents for non-equivalent terms. In German it can be Waldförderungskomplexe which is a calque from Polish, and in English it can be a Promotional Forest Complex which is also a calque. According to Bhabha's third space theory, there is space in-between, the discussed terms do not share common meaning.

\subsection{Służba leśna-Forest Service-Forstdienst}

In Poland, people who take care of forest wildlife and the forests themselves are called Stużba Leśna (lit. forest service). According to the Polish Act on Forest (Dz. U. no. 22, item 1463) an employee of the Forest Service may be a person who:

(1) is a Polish citizen;

(2) is over 21 years old;

(3) has full civil capacity and civic rights;

(4) has appropriate professional qualifications;

(5) has an impeccable reputation;

(6) is employed full-time;

(7) is in good health; 
(8) has not been punished by a court for a crime of profit or other low motives. ${ }^{8}$

The Forest Service employs people called leśniczy —a forester, or a forest ranger. The forester is subordinate to a forest inspector and superior to a deputy forester, taking care of the forestry entrusted to him, within which he performs technical, economic, protective, administrative and accounting activities. The forestry includes forests in Poland belonging to the State Treasury, as well as private forests entrusted to the management of local representatives known as starosts.

In the UK, there is a special Forest Service, which is an Executive Agency within the Department of Agriculture and Rural Development, but in the act "the appropriate forestry authority" is mentioned, which means:

a. in relation to England "the Commissioners" (that is e.g. The Forestry Commission);

b. in relation to Wales "the Natural Resources Body for Wales".

This body is of a much higher ranking than the one in Poland (Służba Leśna). It was established in 1919 to address the lack of timber after the 1st World War. This body is of an administrative and legal nature. The Forestry Commission is also the government body responsible for the regulation of private forestry in England; felling is generally illegal without first obtaining a license from the Commission. The Commission is also responsible for encouraging new private forest growth and development. Part of this role is carried out by providing grants in support of private forests and woodlands. The Commissioners consist of a chairman and not more than nine other members appointed by Her Majesty by warrant under the sign manual to be Forestry Commissioners. What is more, of those persons appointed to be Forestry Commissioners:

a. At least three shall be persons who have special knowledge and experience of forestry;

b. At least one shall be a person who has scientific attainments and a technical knowledge of forestry; and

c. At least one shall be a person who has special knowledge and experience of the timber trade [cf. 49].

\footnotetext{
8 2. Pracownikiem Służby Leśnej może być osoba, która:

(1) jest obywatelem polskim;

(2) ukończyła 21 lat;

(3) ma pełnię praw cywilnych i obywatelskich;

(4) posiada odpowiednie kwalifikacje zawodowe;

(5) cieszy się nienaganną opinią;

(6) zatrudniona jest w pełnym wymiarze czasu pracy;

(7) posiada odpowiedni stan zdrowia;

(8) nie była karana sądownie za przestępstwo z chęci zysku lub z innych niskich pobudek. Dziennik Ustaw-22-Poz. 1463.
} 
However, the UK Act does not mention a Forest Service or the position of a Forester. ${ }^{9}$ In the UK there are (similarly as in the USA) rangers. Rangers work with other staff and volunteers to maintain footpaths, gates, stiles and bridges. Moreover, rangers are the eyes and ears of the national park authority, as they are out and about in the national park most of the time. They provide a point of contact between visitors, local people and the national park authority. By comparison, the Stużba leśna in Poland is of a public nature and is state-owned. Rangers have a lot of local knowledge about what to see, where to go, and the wildlife and history of the national park. Answering questions from the public and dealing with local communities are an important part of a ranger's job. There are some qualifications and experience required if someone wants to become a ranger:

1. A degree in conservation, environmental management or similar subject,

2. Experience (volunteering with an environmental organization or joining a national park's volunteer schemes is included as experience),

3. Knowledge and practical skills (rangers need to be good communicators and enjoy working with volunteers and the public).

In the US act, the Forest Service is mentioned. The Organic Act of 1916 created the National Park Service "to conserve the scenery and the natural and historic objects and wildlife therein, and to provide for the enjoyment of the same in such manner and by such means as will leave them unimpaired for the enjoyment of future generations". Both the Forest Service and the National Park Service shall, insofar as practicable, coordinate and correlate such recreational development as each may plan, construct, or permit to be constructed, on lands within their respective jurisdictions which, by mutual agreement, should be given special treatment for recreational purposes [44].

The German Act, (Gesetz über den Vorbereitungsdienst für die Laufbahnen des gehobenen und des höheren Forstdienstes im Lande Nordrhein-Westfalen (Forstdienstausbildungsgesetz NRW-FDAG NRW) vom 19.03.1985), states the requirements for the German forest service, beginning with preparatory service. Persons who have completed a forestry study course at a university suitable for the career with a diploma or master's examination, or an equivalent study course at a university with an examination equivalent to accreditation may be employed in the preparatory service for a career in the higher forestry service. The respective final certificate of the study courses must provide evidence of successful completion of the programme in the core subjects of silviculture/forest ecology, forest nature conservation/landscape management, forest business administration, forest ergonomics, forest utilization, general and subject-related legal and administrative principles, and for the senior forest service, additionally process technology and forest planning [45].

\footnotetext{
${ }^{9}$ Forester. A sworn officer of the forest, appointed by the king's letters patent to walk the forest, watching both the vert and the venison, attaching and presenting all trespassers against them within their own bailiwick or walk.
} 


\begin{tabular}{|c|c|c|c|c|}
\hline & $\begin{array}{l}\text { Polish } \\
\text { Slużba } \\
\text { leśna }\end{array}$ & $\begin{array}{l}\text { German } \\
\text { Forstdienst }\end{array}$ & $\begin{array}{c}\text { American } \\
\text { Forest } \\
\text { Service }\end{array}$ & $\begin{array}{l}\text { British } \\
\text { Forest } \\
\text { Service }\end{array}$ \\
\hline is a Polish citizen & $\checkmark$ & & & \\
\hline is over 21 years old & $\checkmark$ & & & \\
\hline has full civil capacity and civic rights & $\checkmark$ & & & \\
\hline has appropriate professional qualifications & $\checkmark$ & $\checkmark$ & $\checkmark$ & $\checkmark$ \\
\hline has an impeccable reputation & $\checkmark$ & & & \\
\hline is employed full-time & $\checkmark$ & $\checkmark$ & & \\
\hline has an appropriate state of health & $\checkmark$ & & & \\
\hline $\begin{array}{l}\text { has not been punished by a court for a crime } \\
\text { of profit or other low motives }\end{array}$ & $\checkmark$ & & & \\
\hline $\begin{array}{l}\text { the aim is to conserve the scenery and the } \\
\text { natural and historic objects and wildlife } \\
\text { therein, and to provide for the enjoyment of } \\
\text { the same in such manner and by such means } \\
\text { as will leave them unimpaired for the } \\
\text { enjoyment of future generations }\end{array}$ & & & $\checkmark$ & $\checkmark$ \\
\hline $\begin{array}{l}\text { coordinate and correlate such recreational } \\
\text { development as each may plan, construct, or } \\
\text { permit to be constructed, on lands within } \\
\text { their respective jurisdictions which, by } \\
\text { mutual agreement, should be given special } \\
\text { treatment for recreational purposes }\end{array}$ & & & $\checkmark$ & \\
\hline
\end{tabular}

As can be clearly seen from the table above only one feature is in common concerning the profession of a forester. A forester should have appropriate professional qualifications which is mentioned in the Polish, German, American and British Acts and related documents. The other features are mostly completely different in the discussed languages, thus the equivalence in some cases is partial or there is even non-equivalence, as some features like age, citizenship, civil capacity or impeccable reputation are mentioned only in the Polish act. However, the third space of interlingual communication exists, as in each discussed country there are persons responsible for working in and for forests. This is a space inbetween. For a layman, it would have a common meaning, but for a specialist the meaning would be in-between.

\section{Summary}

The language of foresters is a language for specific purposes. Many terms are difficult to understand or translate. The meaning of specific terms are combined with subject content. Moreover, "finding equivalent and adequate terminology requires translators to recognize differences between the cultures of the legal texts with which they work. Legal culture represents the status and behavior of a judicial class." [54]. Our main conclusions are as follows: 
1. Among the eight terms that were discussed, four of them are near equivalents, two of them are partial equivalents and two of them are non-equivalents according to Šarčević [1].

2. When there are non-equivalent terms, the techniques of providing equivalents for nonequivalent terms by Matulewska [5] were provided, e.g. Leśne Kompleksy Promocyjne and its translation into German (Waldförderungskomplexe) and English (Promotional Forest Complex).

3. According to Bhabha's third space theory, there were two types of meanings present in the analysis: common meanings (four terms) and in-between meanings (four terms).

4. The language of foresters is related to the legal system, see for example Germany and Poland.

5. The presented analysis demonstrates that these terms have broader or narrower meanings depending on the country and legal system.

For the purpose of analysis and the limits of the text, the authors chose selected terminology taken from national legal acts concerning forest. In the table below the results are presented in condensed form, showing the equivalents, their types and potential solutions if there is a non-equivalent term in any of the languages under scrutiny.

\begin{tabular}{|c|c|c|c|}
\hline Polish & German & English & $\begin{array}{l}\text { Type of equivalents } \\
\text { according to Šarčević [1] }\end{array}$ \\
\hline las & Wald & Forest & Partial equivalents \\
\hline Lasy państwowe & Staatswald/Landeswald & Public forests & Near equivalents \\
\hline Lasy ochronne & Erholungswald & Recreational forest & $\begin{array}{l}\text { Near equivalence (Polish } \\
\text { and German); } \\
\text { non-equivalence (Pol- } \\
\text { ish and German with } \\
\text { English) }\end{array}$ \\
\hline Parki narodowe & Nationalpark & National parks & $\begin{array}{l}\text { Near equivalents but non- } \\
\text { equivalent in British }\end{array}$ \\
\hline Gospodarka leśna & Waldbewirtschaftung & Forest management & Near equivalents \\
\hline $\begin{array}{l}\text { Klasa bonitacji drzewo- } \\
\text { stanu }\end{array}$ & $\begin{array}{l}\text { Bonitierungsklasse der } \\
\text { Bäume }\end{array}$ & Forest valuation & $\begin{array}{l}\text { Non-equivalence but in } \\
\text { vernacular language } \\
\text { near equivalence } \\
\text { (Polish and German) } \\
\text { or non-equivalence } \\
\text { (between Polish, Ger- } \\
\text { man and English) }\end{array}$ \\
\hline $\begin{array}{l}\text { Leśne kompleksy pro- } \\
\text { mocyjne }\end{array}$ & $\begin{array}{l}- \\
\text { Waldförderungskom- } \\
\text { plexe }\end{array}$ & $\begin{array}{l}- \\
\text { Promotional forest } \\
\text { complex }\end{array}$ & Non-equivalence \\
\hline Służba leśna & Forestdienst & Forest service & Partial equivalence \\
\hline
\end{tabular}

It can be observed that the third space plays a crucial role in finding proper equivalents. Knowing that there is something like a "third space" allows a translator to manoeuvre between languages and, when it is needed, render as near equivalence as possible. The third space is the place where different legal concepts from several 
jurisdictions cross. It is the place where high or low connectivity is discovered, and so near, partial or non-equivalence occur. The analysis has revealed that there is a third space between the terms. High connectivity can be seen in terminology which is considered to be near equivalent, e.g. gospodarka leśna—Waldbewirtschaftung—forest management. There are terms of no connectivity between concepts in legal settings, like park narodowy —national park (American)—geschützte Waldgebiete/Naturschutzgebiete, and no real national parks in British English and in British law. There are also terms of partial equivalence such as stużba leśna—Forestdienst—Forest Service.

In the process of translation the role of a translator is to "fix the semantic source, adjust it for the target language and —if necessary—build meta-linguistic devices to fill the conceptual gap for the target language" [4]. Wagner calls this process a multivariable translational analysis in a third space, whose aim is to help understand in detail "concepts, their purposes, their assumptions, and their limitations in the source space in order to emphasize the similarities and/or differences in both the source and target spaces" [4]. She continues that "the recommended algorithm is that (1) we examine some concepts, (2) process their variables and (3) search for the intercorrelations that the variables may possess in both the source and target spaces. Eventually, from this deciphering process provided by the inter-correlated variables, we could envisage the most appropriate translation" [4]. In this article the authors wanted to see whether "original significances were preserved (heritage) or radically modified (trauma)" [4]. What is more, Smith [54] turns the translators' attention to the fact that:

recognizing a case of absent terminology requires constant comparison between the legal systems of the source and the target languages, as well as being familiar with p-to-date legal literature. (...) «equivalency» refers to equal value between source and target text, and «adequacy» concerns partial dimensions of the text. In the global legal world, where legal traditions and cultures differ so much that one system uses a legal concept completely unknown or even alien to another system, equivalency must also include cultural equivalency. From a linguistic point of view, the ideal translation is one that does not resemble one. Applied to legal texts, a successful translation should communicate the content of a document, all the while employing equivalent accurate syntax, semantics and pragmatics. This is particularly true for legal texts.

To sum up, equivalence may happen to be apparent. For a lay person terms may seem to be $100 \%$ equivalent, but for a specialist, after meticulous analysis of the definitions of terms in different languages, it appears that equivalence is only partial, or sometimes there is even none according to Šarčević [1].

Open Access This article is licensed under a Creative Commons Attribution 4.0 International License, which permits use, sharing, adaptation, distribution and reproduction in any medium or format, as long as you give appropriate credit to the original author(s) and the source, provide a link to the Creative Commons licence, and indicate if changes were made. The images or other third party material in this article are included in the article's Creative Commons licence, unless indicated otherwise in a credit line to the material. If material is not included in the article's Creative Commons licence and your intended use is not permitted by statutory regulation or exceeds the permitted use, you will need to obtain permission directly from the copyright holder. To view a copy of this licence, visit http://creativecommons.org/licenses/by/4.0/. 


\section{References}

1. Šarčević, S. 1997. New approach to legal translation. Hague: Kluwer Law International.

2. Matulewska, A. 2007. Lingua legis in translation. Bern: Peter Lang Publishing House.

3. Rutherford, J. 1990. The third space Interview with Homi Bhabha. In Identity: community, culture, difference, ed. J. Rutherford. London: Lawrence and Wishart Limited.

4. Wagner, A. 2016. A space in-between-legal translation as a "third space." Journal of CivilLaw Studies 9: 168-190.

5. Matulewska, A. 2014. In quest of sufficient equivalence. Polish and English insolvency terminology in translation. a comparative study. Studies in Logic Grammar and Rhetoric 38 (51): 167-188.

6. Vinay \& Darbelnet, 1966 In: Pisarska A. \& T. Tomaszkiewicz. 1996. Współczesne tendencje przekładoznawcze. Poznań: Wydawnictwo Naukowe UAM.

7. Newmark, P. 1982. Approaches to translation. Oxford: Pergamon Press Ltd.

8. Newmark, P. 1988. A textbook of translation. UK: Prentice Hall International Ltd.

9. Newmark, P. 1991. About translation. Clevedon: Multilingual Matters Ltd.

10. Kierzkowska, D. 2002. Ttumaczenie prawnicze. Warszawa: Wydawnictwo TEPIS.

11. Kubacki, A. D. 2012. Tłumaczenie poświadczone. Status, kształcenie, warsztat i odpowiedzialność tłumacza przysięgłego. Warszawa: Wolters Kluwer Business.

12. Raport o stanie lasów w Polsce 2009 (Raport on the state of forests in Poland 2009), Centrum Informacyjne Lasów Państwowych, 2010.

13. Leśkiewicz, K. 2019. Prawne aspekty zarzqdzania lasami skarbu Państwa. Lublin: Wydawnictwo Innovation Press.

14. Art. 31 of German Constitution. Transl. B. Banaszak, A. Malicka, Warszawa 2008, http://libr.sejm. gov.pl/tek01/txt/konst/niemcy.html, 04.09.2020

15. Forestry Facts and Figures 2014: A summary of statistics about woodland and forestry in the UK (PDF). Forestry Commission. 2014-01-01. ISBN 9780855389147.

16. Nix, J., P. Hill, N. Williams, and J. Bough. 1999. Land and estate management, 3rd ed. Chichester: Packard Publishing.

17. Hart, C. 1994. Practical forestry for the agent and surveyor. UK: Sutton Publishing.

18. Focus, Rural. 2012. Forestry policy. Estates Gazette 28: 56-57.

19. "Land Areas of the National Forest System" (PDF). U.S. Forest Service. November 2015. Archived from the original (PDF) on January 16, 2016.

20. “About the Agency”. U.S. Forest Service. Archived from the original on February 21, 2013.

21. Gorte, Ross W.; Cody, Betsy A. (November 7, 1995). "The forest service and bureau of land management: history and analysis of merger proposals". Congressional research service reports for congress. Archived from the original on February 21, 2013.

22. "The National Forests of the United States" (PDF). The forest history society. Archived from the original (PDF) on February 21, 2013.

23. "Find a Forest by State". U.S. Forest Service.

24. Concept of Forest provided by the Anderson Dictionary of Law (1889) (Dictionary of Law consisting of Judicial Definitions and Explanations of Words, Phrases and Maxims and an Exposition of the Principles of Law: Comprising a Dictionary and Compendium of American and English Jurisprudence; William C. Anderson; T. H. Flood and Company, Law Publishers, Chicago, United States

25. US Title 25. Indians; Chapter 33. National Indian Forest Resources Management.

26. US Title 7-Agriculture; Subtitle B-Regulations of the Department of Agriculture; Chapter VI-Natural Resources Conservation Service, Department of Agriculture; Subchapter C-Water Resources; Part 625-Healthy Forests Reserve Program.

27. US Title 16. Conservation; Chapter 86. Southwest Forest Health and Wildfire Prevention.

28. Manw. For. Laws, c. 1, no. 1; Termes de la Ley; 1 B1. Comm. 289.

29. 1 Steph. Comm. 665. Forest courts.

30. "Forest Resources of the United States". May 7, 2009.

31. Federation, Europarc, ed. 2009. Living parks, 100 years of national parks in Europe. München: Oekom Verlag.

32. "Category II: National Park". IUCN. 5 February 2016.

33. "Evolution of the Conservation Movement, 1850-1920". memory.loc.gov.

34. Report of the Superintendent of Yellowstone National Park for the Year 1872 Archived 3 April 2016 at the Wayback Machine, 43rd Congress, 3rd Session, ex. doc. 35, quoting Department of Interior 
letter of 10 May 1872, "The reservation so set apart is to be known as the "Yellowstone National Park'.

35. Gissibl, B., S. Höhler, and P. Kupper. 2012. Civilizing nature. Berghahn, Oxford: National Parks in Global Historical Perspective.

36. Webster's New World College Dictionary, 4th Edition.

37. Collins English Dictionary.

38. "World Heritage List-United States of America". whc.unesco.org. UNESCO World Heritage Centre. Archived from the original on February 25, 2017.

39. "UNESCO » Biosphere Reserves » United States of America". unesco.org. UNESCO. November 2015.

40. "The IUCN categories". www.nationalparks.gov.uk. UK ANPA.

41. Gesetz zur Erhaltung des Waldes und zur Förderung der Forstwirtschaft (Bundeswaldgesetz) https:// www.gesetze-im-internet.de/bwaldg/BJNR010370975.html

42. the Columbia River Gorge National Scenic Area established pursuant to section 544b

43. the Opal Creek Scenic Recreation Area, comprising approximately 13,000 acres, as generally depicted on the map entitled "Proposed Opal Creek Wilderness and Scenic Recreation Area", dated July 1996 and established under subsection (c)(1)(C)

44. (\$460hhh-3. Management)

45. Geltende Gesetze und Verordnungen (SGV. NRW.) mit Stand vom 26.9.2020 https://recht.nrw.de/ 1mi/owa/br_bes_detail?sg=0\&menu=1\&bes_id=4095\&anw_nr=2\&aufgehoben=N\&det_id=185984

46. the Polish Act on Forests of 28th September 1991 [Ustawa z dnia 28 września 1991 r. o lasach].

47. Title 16 U.S. Code Chapter 2-National Forests.

48. Forestry Act 1967, Chapter 10 (the United Kingdom).

49. Forestry and Afforestation in Great Britain. https://www.legislation.gov.uk/ukpga/1967/10/body/ enacted/data.xht?view $=$ snippet\&wrap=true

50. Trzaskawka, Paula. 2017. Investigating trademark terminology and collocations in Polish, English, Japanese and German. International Journal of Law, Language and Discourse 7 (1): 19-32.

51. Schuck A., R. Päivinen, T. Hytönen \& B. Pajari. 2002. Compilation of forestry terms and definitions. European Forest Institute Internal Report No. 6.

52. European Commission. 1997. Study on European Forestry Information and Communication System-Reports on Forestry inventory and survey systems. Vol. 1 \& 2. Luxembourg.

53. Jan Jerzy Karpiński et al. 1991. Mała Encyklopedia Leśna. Warszawa: PWN.

54. Smith, S.A. 1995. Culture clash: anglo-american case law and German civil law in translation. In Translation and the Law, ed. Morris Marshall. American Translators Association Scholarly Monograph Series, Amsterdam: John Benjamins Publishing Company.

Publisher's Note Springer Nature remains neutral with regard to jurisdictional claims in published maps and institutional affiliations.

\section{Authors and Affiliations}

\section{${\text { Paula Trzaskawka }{ }^{1} \text { (D) . Joanna Kic-Drgas }}^{1}$}

\section{Paula Trzaskawka}

paula.trzaskawka@amu.edu.pl

Joanna Kic-Drgas

j.drgas@amu.edu.pl

1 Adam Mickiewicz University in Poznań, Poznań, Poland 